\title{
PARTISIPASI MASYARAKAT PADA PROGRAM DESA MANDIRI PANGAN DI KABUPATEN BANDUNG
}

\author{
Encang Saepudin, Ninis Agustini Damayani, dan Agung Budiono \\ Fakulta Ilmu Komunikasi, Universitas Padjadjaran \\ E-mail: encang@unpad.ac.id
}

\begin{abstract}
ABSTRAK. Penelitian ini mengkaji tentang Partisipasi Masyarakat Pada Program Desa Mandiri Pangan di Kabupaten Bandung. Dengan menggunakan metode deskriptif dan teknik pengumpulan data melalui penyebaran angket, wawancara, Focus Group Discussion, observasi, dan studi pustaka, penelitian ini bertujuan untuk mengetahui tingkat partisipasi masyarakat pada tahap perencanaan, pelaksanaan, pengambilan manfaat, dan evaluasi. Penelitian ini bermanfaat sebagai sebuah bentuk evaluasi program terutama terhadap implementasi kebijakan pemerintah. Selain itu, sebagai masukan bagi pemerintah Kabupaten Bandung terutama Badan Ketahanan Pangan dan Pelaksana Penyuluhan (BKPPP) dalam mengiplementasikan program desa mandiri pangan. Hasil penelitian menunjukkan bahwa tingkat partisipasi masyarakat baik pada tahap perencanaan, pelaksanaan, pengambilan manfaat, dan evaluasi dapat dikategorikan positif artinya partisipasi masyarakat dinilai cukup aktif. Hal ini didasarkan pada hasil perhitungan statistik yang menggambarkan bahwa nilai median lebih kecil dari nilai skor dan nilai skor lebih kecil dari nilai kuartil III. Berdasarkan hasil pengolahan data, penelitian ini dapat disimpulkan bahwa tingkat partisipasi masyarakat pada program desa mandiri pangan dii kabupaten bandung adalah positif.
\end{abstract}

Kata kunci: Partisipasi, masyarakat, desa mandiri pangan, pangan

\section{PARTICIPATION OF COMMUNITIES TOWARD THE VILLAGE FOOD INDEPENDENT PROGRAM IN BANDUNG REGENCY}

\begin{abstract}
This study examines the Participation of the Community towards the Village Food Independent Program in Bandung Regency. By using descriptive method and data collecting technique through questionnaires, interview, Focus Group Discussion, observation, and literature study, this study aims to determine the level of community participation in the planning, implementation, benefit, and evaluation phases. This research is useful as a form of program evaluation especially on the implementation of government policy. In addition, it is also an input for the government of Bandung Regency, especially Food Security Agency and Executing Agency (BKPPP) in implementing the village independent food program. The results showed that the community participation both in the planning, implementation, benefit, and evaluation phases can be categorized as positive, which mean that the community participation is considered adequately active. This is based on the results of statistical calculations which illustrate that the median value is less than the score and the score is smaller than the value of quartile III. Based on the results of data processing, this study can conclude that the community participation towards the program of independent village food in Bandung Regency is positive.
\end{abstract}

Keywords: Participation, society, food independent village, food

\section{PENDAHULUAN}

Menurut Sartono Kartodirjo dalam Hari Poerwanto (2000:197), mengemukakan bahwa sebagian besar masyarakat desa di Indonesia diliputi oleh sindrom kemiskinan dan sindrom enersia. Sindrom kemiskinan memiliki dimensi yang amat kompleks dan satu dengan yang lainnya saling berkaitan, misalnya dalam bentuk tingkat produktivitas yang rendah, pengangguran, kurang gizi dan derajat kesehatan yang buruk, tingkat morbiditas dan buta huruf yang tinggi. Sementara itu sindrom enersia terwujud pada sikap fatalisme, passivisme, rasa saling ketergantungan yang tinggi, kehidupan serba mistik dan sebagainya. Jika dikaji lebih lanjut, kedua jenis sindrom tadi diakibatkan oleh berbagai faktor yang saling berkaitan, antara lain ketimpangan pemilikan dan distribusi tanah, pelapisan sosial yang rancu, kurangnya pemanfaatan sumber daya dan sebagainya.

Salah satu upaya untuk mengatasi masalah kerawanan pangan dan kemiskinan di pedesaan adalah melalui Program Desa Mandiri Pangan. Desa Mandiri Pangan adalah desa yang masyarakatnya mempunyai kemampuan untuk mewujudkan ketahanan pangan dan gizi sehingga dapat menjalani hidup sehat dan produktif dari hari kehari, melalui pengembangan sistem ketahanan pangan yang meliputi subsistem ketersediaan, subsistem distribusi, dan subsistem konsumsi dengan memanfaatkan sumberdaya setempat secara berkelanjutan. (Pangan, B. K. 2006), (Indonesia, B. K. P. R. 2011). Dalam Peraturan Menteri Pertanian Nomor : 25/Permentan/Ot.140/2/2010 disebutkan bahwa pemerintah melalui Badan Ketahanan Pangan Kementerian Pertanian, sejak tahun 2006 telah meluncurkan Program Aksi Desa Mandiri Pangan (Proksi Desa Mapan). Dari program ini diharapkan masyarakat desa mempunyai kemampuan untuk mewujudkan ketahanan pangan dan gizi sehingga dapat menjalani hidup sehat dan produktif dari hari ke hari, secara berkelanjutan. Upaya tersebut dilakukan melalui proses pemberdayaan masyarakat untuk mengenali potensi dan kemampuannya, mencari alternatif peluang dan pemecahan masalah serta mampu mengambil keputusan untuk memanfaatkan sumberdaya alam secara efisien dan berkelanjutan menuju Gerakan Kemandirian Pangan (Gema Pangan). 
Upaya tersebut dilakukan melalui proses pemberdayaan masyarakat untuk mengenali potensi dan kemampuannya, mencari alternatif peluang dan pemecahan masalah serta mampu mengambil keputusan untuk memanfaatkan sumberdaya alam secara efisien dan berkelanjutan sehingga tercapai kemandirian. Permasalahan dan tantangan dalam pembangunan ketahanan pangan secara umum menyangkut pertambahan penduduk, semakin terbatasnya sumber daya alam, beralih fungsinya lahan pertanian, masih terbatasnya prasarana dan sarana usaha di bidang pangan, semakin ketatnya persaingan pasar dengan produk impor, dan besarnya proporsi penduduk miskin. Penduduk miskin yang rawan pangan serta rentan terhadap masalah kerawananan pangan masih cukup tinggi. Penyebabutama kerawanan pangan dan kemiskinan adalah rendahnya pendapatan masyarakat miskin yang mengakibatkan daya beli masyarakat berkurang. (Mulyono, A. 2008)). Keterbatasan kemampuan masyarakat dalam mengakses pangan; serta keterbatasan aset dan akses terhadap sumber daya untuk mengembangkan usaha mikro.

Kerawanan pangan terjadi manakala rumah tangga, masyarakat atau daerah tertentu mengalami ketidak cukupan pangan untuk memenuhi standar kebutuhan fisiologis bagi pertumbuhan dan kesehatan para individu anggotanya. Kerawanan pangan dibedakan atas kerawanan kronis, yaitu yang terjadi terus menerus karena ketidakmampuan membeli atau memproduksi pangan sendiri, dan kerawanan sementara yang terjadi karena kondisi tak terduga seperti bencana alam atau bencana lainnya. Kerawanan pangan, apabila terjadi terus menerus, akan berdampak pada penurunan status gizi dan kesehatan (Badan Ketahanan Pangan 2009).

Kemiskinan adalah situasi serba kekurangan yang terjadi bukan karena dikehendaki si miskin, melainkan karena tidak dapat dihindari oleh kekuatan yang ada padanya. Inti daripada devenisi ini adalah situasi serba kekurangan yang tidak dapat dihindari oleh si miskin. (Safi'i 2011:24). Penduduk miskin ini memiliki resiko tinggi dan rentan mengalami kerawanan pangan. Apabila program-program pemantapan ketahanan pangan kurang memperhatikan kelompok ini maka akan berdampak meningkatkan kemiskinan/kerawanan pangan dan status gizi yang rendah. Kerawanan pangan terjadi manakala rumah tangga, masyarakat atau daerah tertentu mengalami ketidakcukupan pangan untuk memenuhi standar kebutuhan fisiologis bagi pertumbuhan dan kesehatan para individu anggotanya. Kerawanan pangan dibedakan atas kerawanan kronis, yaitu yang terjadi terus menerus karena ketidakmampuan membeli atau memproduksi pangan sendiri. Selain itu, kerawanan sementara yang terjadi karena kondisi tak terduga seperti bencana alam atau bencana lainnya. Kerawanan pangan, apabila terjadi terus menerus, akan berdampak pada penurunan status gizi dan kesehatan.

Perwujudan ketahanan pangan nasional dimulai dari pemenuhan pangan di wilayah terkecil yaitu pedesaan sebagai basis kegiatan pertanian. Basis pembangunan perdesaan bertujuan untuk mewujudkan ketahanan pangan dalam suatu wilayah yang mempunyai keterpaduan sarana dan prasarana dari aspek ketersediaan, distribusi dan konsumsi pangan untuk mencukupi dan mewujudkan ketahanan pangan rumah tangga. (Suryana, A, 2008). Disamping itu membangun daerah pedesaan sangat penting terutama dalam hal penyediaan bahan pangan untuk penduduk, penyedia tenaga kerja untuk pembangunan, penyedia bahan baku untuk industri, dan penghasil komoditi untuk bahan pangan dan ekspor. Karena itu, desa merupakan salah satu entry point untuk masuknya berbagai program yang mendukung terwujudnya ketahanan pangan di tingkat rumah tangga, yang secara kumulatif akan mendukung terwujudnya ketahanan pangan di tingkat kabupaten/kota, propinsi, dan nasional.

Program Desa Mandiri Pangan adalah program pembangunan yang bersifat partisipatif yang mengamanatkan adanya pelibatan masyarakat secara aktif pada setiap tahapan kegiatan, yang mengarah pada bertemunya pendekatan pembangunan top down dan bottom up. (Damayani, N. A., Rachmawati, T. S., Budiono, A., \& Saepudin, E, 2015) Secara riil operasional program baik dalam penentuan lokasi dan operasional awal pelaksanaan program terdapat kesenjangan karena masih menggunakan pendekatan pembangunan yang bersifat top down dalam artian, proses perencanaan, penentuan lokasi, penentuan tahapan kegiatan dan pelaksanaan program awal belum sepenuhnya melibatkan partisipasi masyarakat. Peran dan partisipasi masyarakat berupa tinjauan dan komentar terhadap program merupakan peran yang paling sederhana dari masyarakat belum muncul, sehingga dikhawatirkan dukungan dan rasa memiliki masyarakat terhadap program tidak akan muncul yang berimbas pada capaian program yang kurang maksimal.

Partisipasi masyarakat merupakan keterlibatan masyarakat baik secara langsung maupun tidak langsung dalam setiap tahapan kegiatan Iskandar, J., \& Ginanjar, A. (2002). Sebagaimana mekanisme kerja yang telah diuraikan, terlihat jelas bahwa partisipasi masyarakat memang masih kurang dalam semua tahapan kegiatan program desa mandiri pangan mulai dari tahap perencanaan, pelaksanaan, pengendalian, pengawasan serta evaluasi. Oleh karena itu, kita tidak dapat pungkiri bahwa program desa mandiri pangan hanya bisa berhasil jika mendapat respon dan perhatian dari masyarakat. Dari apa yang terjadi di Kecamatan Cikancung kita bisa melihat bahwa salah satu faktor pendukung dari pelaksanaan desa mandiri pangan adalah tingginya respon masyarakat terhadap desa mandiri pangan itu sendiri. Masyarakat menyadari betul bahwa berpartisipasi dalam program desa mandiri pangan ini berarti turut serta dalam berpartisipasi dalam pembangunan desa. Sehingga proses pelaksanaan desa mandiri pangan menjadi lebih lancar.

Pengertian dan Prinsip Partisipasi Masyarakat Menurut Ach. Wazir Ws (Ach. Wazir Ws et al, 1999, 
29) partisipasi bisa diartikan sebagai keterlibatan seseorang secara sadar ke dalam interaksi sosial dalam situasi tertentu. Dengan pengertian itu, seseorang bisa berpartisipasi bila ia menemukan dirinya dengan atau dalam kelompok, melalui berbagai proses berbagi dengan orang lain dalam hal nilai, tradisi, perasaan, kesetiaan, kepatuhan dan tanggungjawab bersama. Akhmaddhian, S. (2017). Bentuk partisipasi yang diberikan masyarakat tersebut tidak hanya bisa dilihat dari barang ataupun material saja, melainkan bentuk partisipasi yang diberikan dapat dilihat melalui sumbangan tenaga selama proses pelaksanaan kegiatan, sumbangan waktu dan pikiran, begitupun juga sumbangan dalam bentuk lahan dan material bagi kepentingan desa mandiri pangan itu sendiri yang pada akhirnya akan kembali juga manfaatnya kepada masyarakat itu sendiri. Dalam program desa mandiri pangan keterlibatan masyarakat menjadi syarat mutlak kelancaran dan keberhasilan program tersebut. Hal tersebut disebabkan oleh program ini memang menginginkan adanya pelembagaan pengelolaan pembangunan partisipatif dengan mendayagunakan potensi dan sumberdaya lokal.

Keterlibatan masyarakat dalam program desa mandiripangan dimulai dari proses perencanaan program yaitu mulai kehadiran dalam setiap pertemuan yang diadakan oleh penguru desa mandiri pangan. Begitupun ketika dilakukan penggalian gagasan, masyarakat dituntut untuk lebih pro aktif dalam menyampaikan ide, gagasan maupun saran bagi kepentingan pembangunan desa. Setelah proses perencanaan dilakukan masyarakat kembali dituntut partisipasinya dalam bentuk tenaga, waktu, serta material dalam proses pelaksanaan kegiatan yang telah direncanakan tersebut. Begitupun setelah pelaksanaan kegiatan dilakukan masyarakat dituntut untuk lebih proaktif dalam memanfaatkan serta menjaga dan memelihara hasil dari program tersebut sehingga apa yang menjadi tujuan dari desa mandiri pangan tersebut dapat tercapai.

Berdasarkan uraian diatas maka masalah yang diangkat dirumuskan dalam bentuk pertanyaan penelitian, yaitu Bagaimana partisipasi masyarakat pada tahap pengambilan keputusan/ perencanaan, pelaksanaan program, pengambilan manfaat, dan evaluasi dalam program desa mandiri pangan di Desa Mekarlaksana Kecamatan Cikancung Kabupaten Bandung? Berdasarkan kepada rumusan masalah tersebut tujuan penelitian ini adalah Untuk Mengetahui Partisipasi masyarakat pada tahap pengambilan keputusan/ perencanaan, pelaksanaan program, pengambilan manfaat, dan evaluasi dalam program desa mandiri pangan di Desa Mekarlaksana Kecamatan Cikancung Kabupaten Bandung.

\section{METODE}

Metode yang digunakan dalam penelitian ini adalah metode mixed methods. Penelitian ini merupakan suatu langkah penelitian dengan menggabungkan dua bentuk penelitian yang telah ada sebelumnya yaitu penelitian kualitatif dan penelitian kuantitatif. Menurut Creswell (2010: 5), penelitian campuran merupakan pendekatan penelitian yang mengkombinasikan antara penelitian kualitatif dengan penelitian kuantitatif. Dalam penelitian ini menggunakan strategi metode campuran sekuensial/ bertahap (sequential mixed methods) terutama strategi eksploratoris sekuensial. Sequential explanatory designs, pengumpulan data kuantitatif dan kualitatif dilaksanakan dalam dua tahap, dengan penekanan utama pada metode kuantitatif.

\section{Populasi dan Sampel}

Populasi adalah wilayah generalisasi objek/subjek yang memiliki kualitas dan karakteristik tertentu yang ditetapkan oleh peneliti untuk dipelajari dan kemudian di tarik kesimpulan. Populasi dalam penelitian merupakan sumber data yang terdiri dari sekelompok subjek, gejala atau objek. Hal ini sesuai dengan pendapat Prijana $(2005,4)$ yang mengemukakan bahwa, "Populasi adalah keseluruhan unit-unit observasi yang karakteristiknya akan diduga". Yang menjadi populasi dalam penelitian ini adalah Masyarakat yang tergabung dalam kelompok afinitas di Desa Mekarlaksana Kecamatan Cikancung. Ukurang populasi penelitian ini adalah seluruh anggota afinitas dengan jumlah 180 orang. Sesuai dengan Peraturan Menteri Pertanian Nomor: 25/Permentan/Ot.140/2/2010 Kelompok afinitas dalam penelitian adalah kelompok yang tumbuh atas dasar ikatan kebersamaan dan kecocokan antar anggota yang mempunyai kesamaan visi dan misi dengan memperhatikan sosial budaya setempat.

Sampel adalah bagian dari jumlah dan karakteristik yang dimiliki oleh populasi tersebut. Yang menjadi populasi dan sempel dalam penelitian ini adalah Masyarakat yang tergabung dalam kelompok afinitas di Desa Mekarlaksana Kecamatan Cikancung. Untuk dapat menentukan jumlah sampel dan agar sampel yang diambil dapat mewakili keseluruhan populasi (representatif) maka digunakanlah teknik pengambilan sampel (sampling) simple random sampling (Sampel acak sederhana), hal ini disebabkan jenis populasi yang relatif homogen atau sama (Sugiyono 2011, 82).

Untuk memperoleh ukuran sample yang representatif, maka penulis menggunakan rumus Taro Yamane, yaitu sebagai berikut :

$$
n=\frac{\mathrm{N}}{\mathrm{N} \mathrm{d}^{2}+1}
$$

Keterangan:

$\mathrm{n}$ : jumlah sample

$\mathrm{N}$ : jumlah populasi

d : tingkat perkiraan kesalahan $10 \%$

(Jalaludin Rahmat 2005,82)

Berdasarkan rumus tersebut maka ukuran sampelnya dapat dihitung sebagai beriut; 
$n=\frac{180}{180(0.1)^{2}+1}=64,28$ dibulatkan menjadi 65 orang

Sampel yang diambil adalah 65 orang.

\section{Pengukuran Tingkat Partisipasi Masyarakat}

Kuesioner yang diberikan kepada responden, berupa pernyataan tertutup mengenai partisipasi masyarakat dalam pelaksanaan program desa mandiri pangan di Desa Mekarlaksana Kecamatan Cikancung Kabupaten Bandung. Setiap pernyataan yang diajukan, responden hanya perlu menjawab satu pilihan jawaban yang tersedia. Butir-butir pernyataan yang diajukan mengacu pada tolak ukur yang telah ditetapkan sebelumnya. Jawaban-jawaban yang tercantum dalam kuesioner mengacu pada skala likert. Pertanyaan yang ada dalam kuesioner masing-masing jawaban diberi skor sebagai berikut.

Tabel 1. Alternatif Jawaban Responden dan Skor Penilaian

\begin{tabular}{|c|c|c|}
\hline \multirow[b]{2}{*}{ Pilihan jawaban } & \multicolumn{2}{|c|}{ Skor masing-masing pernyataan } \\
\hline & $\begin{array}{c}\text { Pernyataan } \\
\text { positif }\end{array}$ & $\begin{array}{c}\text { Pernyataan } \\
\text { negatif }\end{array}$ \\
\hline Sangat tidak setuju & 1 & 5 \\
\hline Tidak setuju & 2 & 4 \\
\hline Tidak ada pendapat & 3 & 3 \\
\hline Setuju & 4 & 2 \\
\hline Sangat setuju & 5 & 1 \\
\hline
\end{tabular}

Setelah dilakukan uji validitas dan reliabilitas, selanjutnya adalah menganalisis data yang telah didapatkan dengan mengggunakan model analisis deskriptif. Model analisis ini menjelaskan pernyataan responden dengan mendeskripsikannya melalui penggunaan tabel dan pengukurannya menggunakan skala likert. Berdasarkan hal tersebut, maka jumlah skor dari seluruh responden adalah:

Tabel 2. Jumlah Skor Seluruh Responden

\begin{tabular}{|l|l|}
\hline Maksimal & 65 responden $\times 5=325$ \\
\hline Minimal & 65 responden $\times 1=65$ \\
\hline Median & 65 responden $\times 3=195$ \\
\hline Kuartil I & 65 responden $\times 2=130$ \\
\hline Kuartil III & 65 responden $\times 4=260$ \\
\hline
\end{tabular}

Jumlah skor tersebut kemudian dianalisis dengan menggunakan beberapa pendekatan (Sugiyono,2008), untuk menentukan seberapa besar tingkat partisipasi masyarakat, sebagai berikut :

a. Jika Kuartil III < Skor $<$ Maksimal; artinya sangat positif (partisipasi masyarakat dinilai aktif).

b. Jika Median < Skor < Kuartil III; artinya positif (partisipasi masyarakat dinilai cukup aktif).

c. Jika Kuartil I < Skor < Median; artinya negatif (partisipasi masyarakat dinilai kurang aktif).

d. Jika Minimal < Skor < Kuartil I; artinya sangat negatif (partisipasi masyarakat dinilai tidak aktif).
Apabila dipersentasekan, maka besar tingkat partisipasi masyarakat dapat dihitung berdasarkan rumusan sebagai berikut:

Skor yang diperoleh

Tingkat partisipasi = -----------------------x 100

Skor maksimal

Pada bagian ini akan diukur mengenai tingkat partisipasi masyarakat berdasarkan tolak ukur yang ada pada masing-masing variabel. Untuk mempermudah pengolahan data, data yang diperoleh kemudian diolah dengan menggunakan Microsoft Excel.

\section{HASIL DAN PEMBAHASAN}

Melalui program desa mandiri pangan diharapkan masyarakat mempunyai kemampuan untuk mewujudkan ketahanan pangan dan gizi. Upaya tersebut dilakukan melalui proses pemberdayaan masyarakat. Upaya ini untuk mengenali potensi dan kemampuannya, mencari alternatif peluang dan pemecahan masalah, serta mampu mengambil keputusan untuk memanfaatkan sumberdaya alam secara efisien dan berkelanjutan. Dengan demikian akan tercapai kemandirian pangan masyarakat. Pemberdayaan masyarakat dilakukan dengan menempatkan tenaga pendamping di setiap desa pelaksana selama empat tahun berturut-turut. Hal ini dilaksanakan sesuai tahapan program yaitu pada tahap persiapan, penumbuhan, pengembangan, dan kemandirian.

Dalam pelaksanaan program desa mandiri pangan, kondisi awal partisipasi masyarakat sangat perlu diketahu. Hal ini karena keberhasilann program ini sangat ditentukan oleh peran dan partisipasi masyarakat sasaran. Kondisi partisipasi masyarakat Kecamatan Cikancung dapat digambarkan dengan potensi dan kendala yang berasal dari masyarakat setempat. Potensi partisipasi masyarakat adalah;

1. Kebiasaan gotong-royong dan kesadaran kebersamaan sudah tumbuh, seperti kegiatan terjadwal dalam melaksanakan kegiatan di pedesaan.

2. Kelembagaan di tingkat lokal dalam menyikapi kondisi dan dinamika pembangunan yang berkembang cukup baik, hal ini dikoordinasikan oleh tokoh-tokoh setempat.

3. Kesadaran terhadap pengembangan potensi desa telah dimiliki oleh masyarakat. Hal ini berpotensi untuk pengembangan ekonomi pedesaan berbasis masyarakat.

4. Motivasi masyarakat untuk maju dan bersaing sudah ada.

Sedangkan faktor yang menjadi kendala dalam meningkatkan partisipasi masyarakat Kecamatan Cikancung dalam kegiatan pengembangan desa mandiri pangan adalah; 
1. Perbedaan kepentingan yang ada di masyarakat. Hal ini, berpotensi menjadi konflik.

2. Lembaga-lembaga desa belum maksimal untuk dapat mengakomodir dan melihat kebutuhan masyarakat.

3. Kurangnya pengetahuan masyarakat mengenai pengembangan desa mandiri pangan.

4. Keterbatasan kreatifitas dan inovasi untuk mengembangkan ekonomi di tingkat lokal yang mendukung program pembangunan.

Partispasi masyarakat dalam program desa mandiri pangan adalah keterlibatan masyarakat secara langsung dalam setiap tahapan kegiatan mulai dari perencanaan kegiatan, pelaksanaan kegiatan, dan pemeliharaan pada program fisik maupun non fisik. Pola partisipasi masyarakat memang cukup dominan dalam semua tahapan kegiatan program desa mandiri pangan mulai dari tahap perencanaan, pelaksanaan, serta pemeliharaan hasil kegiatan. Oleh karena itu, tidak dapat di pungkiri bahwa program desa mandiri pangan hanya bisa berhasil jika mendapat respon dan perhatian dari masyarakat. Partisipasi masyarakat didalam tahapan desa mandiri pangan dapat dilihat dari tiga sisi yaitu Partisipasi dalam perencanaan, pelaksanaan, dan pemeliharaan hasil kegiatan.

\section{Partisipasi dalam Pengambilan Keputusan/ Perencanaan}

Variabel ini memiliki enam indikator yaitu a. Informasi mengenai program desa mandiri pangan didapatkan melalui kelurahan atau RT/RW setempat, b. Pemberitahuan mengenai adanya program desa mandiri pangan bagi masyarakat dilakukan secara jelas, c. Masyarakat mencari tahu lebih jauh mengenai program desa mandiri pangan, d. Pernah diajak musyawarah untuk membahas perencanaan program desa mandiri pangan, e Pernah memberikan masukan gagasan/ ide dalam program desa mandiri pangan, dan $\mathrm{f}$. Keterlibatan masyarakat dalam program desa mandiri pangan harus dari awal kegiatan sampai akhir kegiatan, Berikut adalah perhitungan dari tiap indicator/ tolak ukur tersebut:

Tabel 3. Partisipasi dalam Pengambilan Keputusan/ Perencanaan

\begin{tabular}{|c|c|c|c|c|}
\hline No & Tolak ukur & Skor & Kuartil III & Maksimal \\
\hline 1 & $\begin{array}{l}\text { Informasi mengenai } \\
\text { program desa mandiri } \\
\text { pangan }\end{array}$ & 287 & 260 & 325 \\
\hline 2 & Kejelasan Informasi & 255 & 260 & 325 \\
\hline 3 & $\begin{array}{l}\text { Masyarakat mencari } \\
\text { tahu lebih jauh }\end{array}$ & 211 & 260 & 325 \\
\hline 4 & $\begin{array}{l}\text { Pernah diajak } \\
\text { musyawarah }\end{array}$ & 290 & 260 & 325 \\
\hline 5 & $\begin{array}{l}\text { Pernah memberikan } \\
\text { masukan gagasan/ ide }\end{array}$ & 265 & 260 & 325 \\
\hline \multirow[t]{3}{*}{6} & $\begin{array}{l}\text { Keterlibatan } \\
\text { masyarakat }\end{array}$ & 262 & 260 & 325 \\
\hline & Total & 1570 & & \\
\hline & Rata-rata & 261.66 & & \\
\hline
\end{tabular}

Data di atas menggambarkan bahwa partisipasi masyarakat dalam pengambilan keputusan/ Perencanaan program desa mandiri pangan cukup tinggi. Hal ini terlihat dari rata-rata skor yang diperoleh adalah 261, 66. Skor tersebut jauh lebih tinggi dari skor median yakni 195 bahkan ada diatas nilai kuartil III yakni 260. Berdasarkan kepada angka skor yang ada diatas kwartil III maka tingkat partisipasi mayarakat dapat dikategorikan sangat positif. Hal ini berarti bahwa tingkat partisipasinya dinilai aktif. Apabila skor komulatif dari sub variabel ini dipresentasekan maka dapat dihitung sebagai berikut; 261.66

$$
\begin{aligned}
\text { Tingkat partisipasi V1= } & -----------\times 100 \\
& 325 \\
= & 80.51
\end{aligned}
$$

Presentase partisipasi masyarakat pada tahap perencanaan ini mencapai $80,51 \%$. Hal ini berarti hampir setiap tahapan perencanaan masyarakat ikut terlibat atau dilibatkan. Tingkat partisipasi ini terjadi disebabkan oleh keterbukaan para pengelola program desa mandiri pangan yang dimotori oleh pihat pemerintahan desa Mekarlaksana. Partisipasi masyarakat dalam proses perencanaan kegiatan desa mandiri pangan dapat dilihat dari kehadiran masyarakat pada proses perencanaan program yang dilakukan oleh pelaku Tim Pengelola Kegiatan (TPK) di tingkat dusun/lingkungan. Kegiatan atau tahapan desa mandiri pangan utamanya dalam musyawarah di tingkat desa harus memperhatikan jadwal atau kegiatan sehari-hari masyarakat sebagai sasaran program. Hal ini sangat penting, mengingat bahwa dalam proses penentuan prioritas kegiatan disitulah letak awal perencanaan pembangunan yang akan dilakukan. Pada tahap ini keterlibatan masyarakat sangat diperlukan untuk mengetahui apa yang menjadi kebutuhan mereka.

Selanjutnya dalam proses penentuan prioritas kegiatan ini, masyarakat tidak hanya dituntut kehadirannya, tetapi masyarakat dituntut untuk lebih aktif menyampaikan ide, usulan, serta kebutuhan mereka serta penentuan jenis kegiatan yang dibutuhkan. Dari hasil wawancara dengan Fasilitator bidang pemberdayaan UPK Kecamatan Cikancung mengenai partisipasi masyarakat dalam perencanaan program desa mandiri pangan menyatakan bahwa: Perlu kita pahami bersama bahwa keaktifan masyarakat dalam menyampaikan ide atau gagasan mencerminkan masyarakat sudah mengerti dan memahami masalah atau kendala yang dihadapi. Pada dasarnya yang tahu dan yang merasakan permasalahan adalah masyarakat itu sendiri. oleh karenanya yang membuat solusi dari permasalahan tersebut harus dari kalangan masyarakat itu sendiri.

\section{Partisipasi Masyarakat dalam Pelaksanaan Program}

Variabel ini memiliki enam indikator yaitu a. Sebagaian dana yang digunakan sebagian modal 
usaha adalah milik pribadi. b. Tempat yang digunakan untuk berusaha adalah milik pribadi. c. Alat usaha yang digunakan dalam menjalankan usaha adalah milik pribadi. d. Setiap kegiatan dalam program desa mandiri pangan selalu didokumentasikan e. Selalu ikut serta dalam pengadministrasian kegiatan $\mathrm{f}$. Fasilitator mudah ditemui oleh anggota program desa mandiri pangan g. Fasilitator sangat berperan dalam pendampingan kelompok. Berikut adalah perhitungan dari tiap indicator/ tolak ukur tersebut:

Tabel 4. Partisipasi Masyarakat dalam Pelaksanaan Program

\begin{tabular}{|c|c|c|c|c|}
\hline No & Tolak ukur & Skor & Median & $\begin{array}{c}\text { Kuartil } \\
\text { III }\end{array}$ \\
\hline 1 & $\begin{array}{l}\text { Sebagaian modal usaha } \\
\text { milik pribadi. }\end{array}$ & 259 & 195 & 260 \\
\hline 2 & $\begin{array}{l}\text { Tempat yang digunakan } \\
\text { untuk berusaha milik } \\
\text { pribadi. }\end{array}$ & 248 & 195 & 260 \\
\hline 3 & $\begin{array}{l}\text { Alat usaha yang } \\
\text { digunakan adalah milik } \\
\text { pribadi. }\end{array}$ & 247 & 195 & 260 \\
\hline 4 & $\begin{array}{l}\text { Setiap kegiatan } \\
\text { dalam program desa } \\
\text { mandiri pangan selalu } \\
\text { didokumentasikan }\end{array}$ & 149 & 195 & 260 \\
\hline 5 & $\begin{array}{l}\text { Selalu ikut serta dalam } \\
\text { pengadministrasian } \\
\text { kegiatan }\end{array}$ & 140 & 195 & 260 \\
\hline 6 & $\begin{array}{l}\text { Fasilitator mudah } \\
\text { ditemui oleh anggota } \\
\text { program desa mandiri } \\
\text { pangan }\end{array}$ & 148 & 195 & 260 \\
\hline 7 & $\begin{array}{lr}\text { Fasilitator } & \text { sangat } \\
\text { berperan dalam } \\
\text { pendampingan kelompok }\end{array}$ & 259 & 195 & 260 \\
\hline & Total & 1450 & & \\
\hline & Rata-rata & 207,14 & 195 & 260 \\
\hline
\end{tabular}

Data di atas menggambarkan bahwa partisipasi masyarakat dalam pelaksanaan program desa mandiri pangan cukup tinggi. Hal ini terlihat dari rata-rata skor yang diperoleh adalah 207.14. Berdasarkan kepada angka skor yang ada diatas median namun ada di bawah skor kuartil III maka tingkat partisipasi mayarakat dapat dikategorikan cukup positif. Hal ini berarti bahwa tingkat partisipasinya cukup aktif. Apabila skor komulatif dari sub variabel ini dipresentasekan maka dapat dihitung sebagai berikut;

$$
\begin{array}{cc} 
& 207,14 \\
\text { Tingkat partisipasi V2 }=\text {---------x } 100 & 325 \\
= & 63,73
\end{array}
$$

Presentase partisipasi masyarakat pada tahap pelaksanaan kegiatan ini mencapai $63.73 \%$. Hal ini berarti hampir setiap tahapan pelaksanaan kegiatan masyarakat ikut terlibat atau dilibatkan. Partisipasi masyarakat dalam pelaksanaan kegiatan dapat dilihat dari keterlibatan masyarakat dalam proses pelaksanaan kegiatan. Utamanya dalam hal pelaksanaan kegiatan non fisik yakni dibidang ekonomi. Melalui keterlibatan masyarakat baik dari segi kesediaan masyarakat dalam meluangkanwaktudantenagasertakesediaanmasyarakat dalam menyediakan bahan/materi yang diperlukan untuk pelaksanaan kegiatan. Dari hasil wawancara dengan Kepala UPK Kecamatan Cikancung mengenai partisipasi masyarakat dalam pelaksanaan program desa mandiri pangan menyatakan bahwa "Partisipasi masyarakat dalam pelaksanaan kegiatan program desa mandiri pangan di Kecamatan Cikancung dilihat dari tingkat kehadiran masyarakat tidak sepenuhnya mencapai $100 \%$. Hal ini dipengaruhi oleh tahapan atau jadwal pelaksanaan kegiatan seringkali berbenturan dengan pekerjaan sehari-hari. Hal ini mengakibatkan masyarakat lebih memprioritaskan pekerjaan sehari-hari mereka sebagai sumber pendapatan utama. Namun dari segi minat secara menyeluruh masyarakat memberikan partisipasi dalam segala kerja kelopok."

Berdasarkan data di atas dari tujuh indikator yang menjadi tolak ukur variabel ini dapat dipilah menjadi dua kelompok. Kelompok pertama menunjukkan skor diatas median dan kelompok kedua skor berada di bawah median. Kelompok pertama yakni a. Sebagaian dana yang digunakan sebagian modal usaha adalah milik pribadi meliki skor 259, b. Tempat yang digunakan untuk berusaha adalah milik pribadi memiliki skor 248, c. Alat usaha yang digunakan dalam menjalankan usaha adalah milik pribad memiliki skor 247, dan d. Fasilitator sangat berperan dalam pendampingan kelompok memiliki skor 259. Kelompok ini menggambarkan mengenai modal, tempat, dan alat uasaha sebagian besar adalah milik dari anggota afinitas. Hal ini menggambarkan bahwa setiap anggota afinitas berusaha untuk terlibat dalam program desa mandiri pangan dengan melibatkan modal, tempat, dan alat usahanya sebagai bagian dari program tersebut. Oleh karena itu, data ini menujukkan betapa besarnya antusiasme masyarakat untuk ikut terlibat/ berpartisipasi dalam program ini.

Kelompok kedua yanki a. Setiap kegiatan dalam program desa mandiri pangan selalu didokumentasikan memiliki skor 149, b Selalu ikut serta dalam pengadministrasian kegiatan memiliki skor 140, dan c. Fasilitator mudah ditemui oleh anggota program desa mandiri pangan memiliki skor 148. Apabila kelompokan komponen-komponen yang termasuk pada kelompok ini adalah komponen adminitrasi dan komunikasi. Komponen administrasi berkaitan dengan proses pendokumentasian kegiatan dan pelaporan. Berdasarkan hasil wawancara dengan para anggota afinitas mereka menyatakan bahwa proses pengadministrasian itu sangat sulit. Apalagi proses pelaporan hasil kegiatan harus slalu lengkap.

Yang kedua adalah proses komunikasi antara anggota kelompok afinitas dengan pendamping atau fasilitator. Berdasarkan hasil wawancara dengan para anggota afinitas fasilitator sulit ditemui. Proses pendampingan tidak begitu lancar. Hal ini terjadi karena 
tersebarnya anggota kelompok afinitas di daerah-daerah yang sulit untuk dijangkau sehinggan koordinasi sulit dilaksanakan secara efektif. Selain itu, kesibukan anggota afinitas dan pendamping juga berpengaruh terhadap kelancaran komunikasi diantara mereka. Anggota afinitas pada umumnya adalah petani dan peternak. Keseharian mereka lebih banyak di kebun dan sawah. Mereka baru berada di rumah atau menjalankan aktifitas lainnya diatas pukul 4 sore. padahal para pendampig datang siang hari sekitar pukul 12-an.

\section{Partisipasi Masyarakat dalam Pengambilan Manfaat}

Variabel partisipasi masyarakat dalam pengambilan manfaat memiliki 4 indikator. Keempat indikator tersebut adalah a. Kemudahan dalam permohonan pengajuan program desa mandiri pangan, b. Kemudahan prosedur dalam mendapatkan modal usaha dari program desa mandiri pangan, c. Adanya program desa mandiri pangan membantu pemecahan masalah usaha yang dihadapi anggota, dan d. Keterampilan anggota kelompok menjadi meningkat dengan pendampingan yang diberikan. Berikut adalah perhitungan dari tiap indicator/ tolak ukur tersebut:

Tabel 5. Partisipasi Masyarakat dalam Pengambilan Manfaat

\begin{tabular}{llccc}
\hline No & Tolak ukur & Skor & Median & Kuartil III \\
\hline 1 & $\begin{array}{l}\text { Kemudahan dalam } \\
\text { permohonan pengajuan } \\
\text { program }\end{array}$ & 118 & 195 & 260 \\
2 & $\begin{array}{l}\text { Kemudahan prosedur dalam } \\
\text { mendapatkan modal usaha } \\
3\end{array}$ & 145 & 195 & 260 \\
& $\begin{array}{l}\text { Adanya program desa } \\
\text { mandiri pangan membantu } \\
\text { pemecahan masalah usaha } \\
\text { yang dihadapi anggota }\end{array}$ & 279 & 195 & 260 \\
\hline $\begin{array}{l}\text { Keterampilan anggota } \\
\text { kelompok menjadi } \\
\text { meningkat }\end{array}$ & 251 & 195 & 260 \\
\hline \multicolumn{1}{c}{ Total } & 793 & \\
\hline & 198,25 & 195 & 260 \\
\hline
\end{tabular}

Data di atas menggambarkan bahwa partisipasi masyarakat dalam pengambilan manfaat program desa mandiri pangan cukup tinggi. Hal ini terlihat dari rata-rata skor yang diperoleh adalah 198,25. Berdasarkan kepada angka skor yang ada diatas median namun ada di bawah skor kuartil III maka tingkat partisipasi mayarakat dapat dikategorikan cukup positif. Hal ini berarti bahwa tingkat partisipasinya cukup aktif. Apabila skor komulatif dari sub variabel ini dipresentasekan maka dapat dihitung sebagai berikut;

$$
\begin{aligned}
\text { Tingkat partisipasi V3= } & \begin{array}{c}
198.25 \\
---------x \\
\end{array} 100 \\
& =61
\end{aligned}
$$

Presentase partisipasi masyarakat pada pengambilan manfaat ini mencapai $61 \%$. Hal ini berarti hampir setiap tahapan pelaksanaan kegiatan masyarakat ikut terlibat atau dilibatkan. Berdasarkan data di atas dari tempat indikator yang menjadi tolak ukur variabel ini dapat dipilah menjadi dua kelompok. Kelompok pertama menunjukkan skor diatas median dan kelompok kedua skor berada di bawah median. Kelompok pertama adalah a. Adanya program desa mandiri pangan membantu pemecahan masalah usaha yang dihadapi anggota memilki skor 279, b. Keterampilan anggota kelompok menjadi meningkat dengan pendampingan yang diberikan memiliki skor 251. Kelompok pertama menunjukkan partisipasi masayarakat cukup tinggi. Hal ini terkait dengan permasalahan pokok yang dihadapi oleh para angota afinitas. Permasalahan utama kelompok afinitas adalah kemampuan sumberdaya manusia dan modal usaha. Dengan adanya program desa mandiri pangan ini kedua masalah tersebut teratasi.

Menurut pera responden, dengan adanya program desa mandiri pangan permasalahan sumberdaya manusia dan permodalan sedikit teratasi. Melalui program ini masyarakat bisa meningkatkan pengetahuan dan keterampilanya sesuai dengan bidang usaha masingmasing, karena dalam program ini ada pelatihanpelatihan yang diberikan oleh para fasilitator atau pendamping. Bagitu pun dengan permodalan, melalui program ini permodalan para anggota sangat dibantu. Namun, berkaitan dengan permodalan ini yang menjadi kesulitannyaadalah prosedurpengajuan bantuankeuangan dan administrasi pertanggung jawaban. Hal ini terlihat dari hasil perhitungan angket yang menggambarkan kedua masalah tersebut sulit buat para anggota afinitas. Data tersebut dapat dilihat pada kelompok kedua.

Kelompok kedua adalah a. Kemudahan dalam permohonan pengajuan program desa mandiri pangan memiliki skor 118 , b. Kemudahan prosedur dalam mendapatkan modal usaha dari program desa mandiri pangan memiliki skor 145 .

\section{Partisipasi Masyarakat dalam Evaluasi}

Variabel partisipasi masyarakat dalam kegiatan evaluasi memiliki enam indicator. Keenam indicator tersebut adalah a. Program desa mandiri pangan sangat baik dan tepat sasaran, b. Program desa mandiri sangat bermanfaat, c. Program desa mandiri pangan dilakukan oleh Pemerintah dan masyarakat. d. Masyarakat terlibat dalam program desa mandiri pangan karena ada keharusan, e. Dalam melakukan perencanaan terhadap program desa mandiri pangan sebaiknya ada pertemuan yang dilakukan setiap akan membuat perencanaan dalam kegiatan. f. Setiap kebijakan dalam program desa mandiri pangan sebaiknya dikonsultasikan kepada masyaraka.

Data di atas menggambarkan bahwa partisipasi masyarakat pada tahap evaluasi program desa mandiri pangan cukup tinggi. Hal ini terlihat dari rata-rata skor yang diperoleh adalah 266,5. Berdasarkan kepada angka skor yang ada diatas kwartil III maka tingkat partisipasi mayarakat dapat dikategorikan sangat positif. Hal ini 
berarti bahwa tingkat partisipasinya dinilai aktif. Apabila skor komulatif dari sub variabel ini dipresentasekan maka dapat dihitung sebagai berikut;

$\begin{aligned} & 266,5 \\ \text { Tingkat partisipasi V4= } & ------\mathrm{x} 100 \\ & 325 \\ = & 82\end{aligned}$

Tabel 6. Partisipasi Masyarakat dalam Evaluasi

\begin{tabular}{|c|c|c|c|c|}
\hline No & Tolak ukur & Skor & Median & Kuartil III \\
\hline 1 & $\begin{array}{l}\text { Program desa mandiri } \\
\text { pangan sangat baik dan } \\
\text { tepat sasaran. }\end{array}$ & 248 & 195 & 260 \\
\hline 2 & $\begin{array}{l}\text { Program desa mandiri } \\
\text { pangan sangat bermanfaat }\end{array}$ & 251 & 195 & 260 \\
\hline 3 & $\begin{array}{l}\text { Program desa mandiri } \\
\text { pangan dilakukan } \\
\text { oleh Pemerintah dan } \\
\text { masyarakat }\end{array}$ & 254 & 195 & 260 \\
\hline 4 & $\begin{array}{l}\text { Masyarakat terlibat } \\
\text { dalam program desa } \\
\text { mandiri pangan karena } \\
\text { ada keharusan }\end{array}$ & 279 & 195 & 260 \\
\hline 5 & $\begin{array}{l}\text { Dalam melakukan } \\
\text { perencanaan terhadap } \\
\text { program desa mandiri } \\
\text { pangan sebaiknya ada } \\
\text { pertemuan yang dilakukan } \\
\text { setiap akan membuat } \\
\text { perencanaan dalam } \\
\text { kegiatan }\end{array}$ & 287 & 195 & 260 \\
\hline 6 & $\begin{array}{l}\text { Setiap kebijakan dalam } \\
\text { program desa mandiri } \\
\text { pangan sebaiknya } \\
\text { dikonsultasikan kepada } \\
\text { masyarakat }\end{array}$ & 280 & 195 & 260 \\
\hline & Total & 1599 & & \\
\hline & Rata-rata & 266,5 & 195 & 260 \\
\hline
\end{tabular}

Presentase partisipasi masyarakat pada tahap evaluasi ini mencapai $82 \%$. Hal ini berarti hampir setiap tahapan kegiatan evaluasi masyarakat ikut terlibat atau dilibatkan. Tingkat partisipasi ini muncul disebabkan oleh pelaksanaan program yang tepat sasaran, pergram ini sangat bermanfaat, dan program ini dijalankan secara bersama-sama oleh masyarakat dan pemerintah.

Apabila dirinci berdasarkan tolak ukur yang digunakan dapat digambarkan sebagai berikut, a. Program desa mandiri pangan di Desa Mekarlaksana Kecamatan Cikancung Kabupaten Bandung sangat baik dan tepat sasaran memiliki skor 248. berdasarkan hasil wawancara dengan para responden bahwa masyarakat yang bias menjadi anggota afinitas harus diseleksi dan disesuaikan dengan kriteria yang telah ditetapkan oleh pemerintan. Jadi tidak bias sembarang orang bias menjadi anggota afinitas. Hal ini sejalan dengan buku pedoman desa mandiri pangan. Di dalam buku tersebut dinyatakan bahwa "Kelompok usaha adalah masyakarat yang mengembangkan usaha secara bersama-sama dan memiliki komoditas sejenis, yang mengarah pada pembentukan cluster. Kelompok usaha ditumbuhkan oleh FKK, LK, dan masyarakat. Kelompok ditetapkan melalui Keputusan Kepala Badan/Dinas/Kantor/unit kerja Ketahanan Pangan Kabupaten/Kota.”

Berikut data mengenai indikator masing-masing b. Program desa mandiri pangan di Desa Mekarlaksana Kecamatan Cikancung Kabupaten Bandung sangat bermanfaat memiliki skor 251, c. Program desa mandiri pangan di Desa Mekarlaksana Kecamatan Cikancung Kabupaten Bandung ini dilakukan oleh Pemerintah dan masyarakat memiliki skor 254. d. Masyarakat terlibat dalam program desa mandiri pangan di Desa Mekarlaksana Kecamatan Cikancung Kabupaten Bandung karena ada keharusan memiliki skor 279, e. Dalam melakukan perencanaan terhadap program desa mandiri pangan sebaiknya ada pertemuan yang dilakukan setiap akan membuat perencanaan dalam kegiatan memiliki skor 287. dan f. Setiap kebijakan dalam program desa mandiri pangan sebaiknya dikonsultasikan kepada masyaraka memiliki skor 280.

Berdasarkan skor komulatif dari masing-mansing sub variabel maka tingkat parisipasi masyarakat dalam program desa mandiri pangan dapat dikelompokkan menjadi dua bagian. Bagian pertama yakni pertisipasi masyarakat dalam pengambilan keputusan/ perencanaan dan partisipasi masyarakat dalam evaluasi program sangat positif. Hal ini karena Kuartil III < Skor < Maksimal; artinya sangat positif (partisipasi masyarakat dinilai aktif). a) Pelaksanaan program apabila digambarkan secara rinci sebagai berikut 260 (kuartil III) < 261.66 (skor) < 325 (nilai maksimal). b) Pelaksanaan program apabila digambarkan secara rinci sebagai berikut 260 (kuartil III) $<266.5$ (skor) $<325$ (nilai maksimal). Bagian kedua yakni partisipasi masyarakat dalam pelaksanaan program dan partisipasi masyarakat dalam pengambilan manfaat positif. Hal ini karena Median < Skor < Kuartil III; artinya positif(partisipasi masyarakat dinilai cukup aktif). a) Pelaksanaan program apabila digambarkan secara rinci sebagai berikut 195 (median) < 207.14 (skor) $<260$ (kuartil III). b) Pelaksanaan program apabila digambarkan secara rinci sebagai berikut 195 (median) < 198.25 (skor) $<260$ (kuartil III).

Apabila skor komulatif dari variabel ini dihitung maka partisipasi masyarakat dalam program desa mandiri pangan adalah positif. Hal ini terlihat dari Median < Skor $<$ Kuartil III artinya positif(partisipasi masyarakat dinilai cukup aktif). Apabila digambarkan secara rinci sebagai berikut 195 (median) < 233,38 (skor) $<260$ (kuartil III). Apabila skor komulatif ini dipresentasekan maka dapat dihitung sebagai berikut;

\section{3,38}

$\begin{array}{rl}\text { Tingkat partisipasi } \mathrm{V}=-------\mathrm{x} & 100 \\ & 325 \\ = & 71,81\end{array}$

Presentase komulatif partisipasi masyarakat pada program desa mandiri pangan ini mencapai 71,81\%. Hal ini berarti hampir setiap tahapan kegiatan masyarakat 
ikut terlibat atau dilibatkan. Tingkat partisipasi ini terjadi disebabkan oleh keterbukaan para pengelola program desa mandiri pangan yang dimotori oleh pihat pemerintahan Desa Mekarlaksana. Oleh karena itu, partisipasi masyarakat pada tahap pengambilan keputusan/perencanaan, pelaksanaan program, pengambilan manfaat, dan evaluasi cukup positif.

\section{SIMPULAN}

Berdasarkan hasil pengolahan data dan analisis deskriptif dari masing-mansing sub variabel maka tingkat parisipasi masyarakat dalam program desa mandiri pangan dapat dikelompokkan menjadi dua bagian. Bagian pertama yakni pertisipasi masyarakat pada pengambilan keputusan/ perencanaan dan evaluasi program sangat positif. Hal ini karena Kuartil III $<$ Skor $<$ Maksimal. Hal ini mengandung arti bahwa partisipasi masyarakat sangat positif atau dapat dimaknai bahwa partisipasi masyarakat dinilai aktif. Bagian kedua yakni partisipasi masyarakat pada pelaksanaan program dan pengambilan manfaat positif. Hal ini karena Median $<$ Skor $<$ Kuartil III. Hal ini mengandung srti bahwa partisipasi masyarakat positif dan dapat dimaknai bahwa partisipasi masyarakat dinilai cukup aktif. Berdasarkan skor komulatif dari masing-mansing sub variabel maka tingkat parisipasi masyarakat dalam program desa mandiri pangan Di Desa Mekarlaksana Kec.Cikancung Kabupaten Bandung adalah positif. Hal ini terlihat dari Median $<$ Skor $<$ Kuartil III artinya positif (partisipasi masyarakat dinilai cukup aktif).

\section{UCAPAN TERIMAKASIH}

Dalam kesempatan ini penulis mengucapkan terima kasih kepada semua pihak yang telah mendukung terlaksananya penelitian ini. Secara Khusus penulis mengucapkan terima kasih kepada Dekan Fakultas Komunikasi Unpad, Direktur DRPMI Unpad, Ketua Program Studi Ilmu Perpustakaan Fakultas Ilmu Komunkasi Unpad, dan Pemerintah Kabupaten Bandung.

\section{DAFTAR PUSTAKA}

Akhmaddhian, S. (2017). Aparatur Peduli Lingkungan, Kebijakan Pemerintah Daerah Kabupaten Kuningan Dalam Konservasi Sumber Daya Air. Sosiohumaniora, 19(3).
Damayani, N. A., Rachmawati, T. S., Budiono, A., \& Saepudin, E. (2015). "Literasi Informasi Masyarakat Pedesaan Dalam Program Pemberdayaan Masyarakat Di Kecamatan Cikancung Kabupaten Bandung" . Jurnal Kajian Informasi dan Perpustakaan, 3(2), 221-234.

PROKSI DESA MAPAN, Evaluasi kegiatan Program Aksi Desa Mandiri Pangan 2009. Badan Ketahanan Pangan.

Indonesia, B.K.P.R. (2011). Pedoman Teknis Program Aksi Desa Mandiri Pangan. Badan Ketahanan Pangan Kementerian Pertanian RI.

Iskandar, J. \& Ginanjar, A. (2002). Perubahan Pengelolaan Hutan oleh Masyarakat Dayak Akibat Kegiatan HPH/HPHH di Kutai Barat Kalimantan Timur. Sosiohumaniora, 4(3), 209.

Mulyono, A. (2008). Studi Partisipasi Masyarakat pada Program Desa Mandiri Pangan Di Desa Muntuk, Kabupaten Bantul (Doctoral dissertation, program Pasca Sarjana Universitas Diponegoro).

Pedoman Umum Program Aksi Desa Mandiri Pangan (Desa Mapan). 2012. Badan Ketahanan Pangan Badan Ketahanan Pangan, Dep. Pertanian RI. Jakarta.

Pangan, B. K. (2006). Pedoman Umum Program Aksi Desa Mandiri Pangan (MAPAN). Depatemen Pertanian.

Prijana, (2005). Metode Sampling Terapan. Bandung: Humaniora

Suryana, A. (2008). Menelisik ketahanan pangan, kebijakan pangan, dan swasembada beras. Pengembangan Inovasi Pertanian, 1(1), 1-16.

Safi'i, M. (2011). Ampih Miskin, Model Kebijakan Penuntasan Kemiskinan dalam Perspektif Teori dan Praktek. Cetakan 1. Averroes Press. www. averroespress.net.

Sugiyono. (2008). Metode penelitian kuantitatif kualitatif dan R \& D . Bandung : Alfabeta.

Sugiyono. (2008). Metode Penelitian Bisnis. Bandung. Alfabeta 